\title{
The Links between Academic Research and Economic Development in Ethiopia: The Case of Addis Ababa University
}

\author{
Mulu Nega Kahsay ${ }^{*}$
}

\section{Addis Ababa University, ETHIOPIA}

*Corresponding Author: mnega2003@yahoo.com

Citation: Mulu, N.K. (2017). The Links between Academic Research and Economic Development in Ethiopia: The Case of Addis Ababa University. European Journal of STEM Education, 2(2), 05. https://doi.org/10.20897/ejsteme.201705

Published: September 2, 2017

\begin{abstract}
This paper aims to examine the major issues concerning the links between academic research and economic development in Ethiopia by considering the Addis Ababa University as a case. The paper is based on two premises. The first pertains to the idea that universities being one of the actors in knowledge production play central role in enhancing the economic development and competitiveness of a country through their missions of academic research and the formation of skilled human capital. The second concerns the argument that a strong collaborative link between Universities and the industry is crucial in enhancing scientific and technological innovation process and commercialization of academic research through technology transfer that is necessary for economic development. Based on a review of the conceptual and theoretical debates, documentary evidences and key informant interviews, the paper argues that the university-industry link/partnership in terms of academic research and innovation is not well developed in the Ethiopian context. The findings indicate that the contribution of academic research in enhancing the country's economic development is minimal at Addis Ababa University in particular and in the country in general. The barriers to the lack of strong link between university and industry in terms of academic research and innovation are discussed and documented. Finally, implications for a strong partnership among universities, industry and government in enhancing the contribution of academic research and innovation to the country's development are dawn.
\end{abstract}

Keywords: academic research, economic development, industry, innovation, knowledge, linkage/partnership, technology transfer, university

\section{BACKGROUND}

In today's world, sustainable development of a country depends to a larger extent on its ability to generate, adopt and apply knowledge. Knowledge and the knowhow to use the available knowledge have now become critical for a country's survival in the dynamic and competitive global environment. Universities have long been recognized as one of the important sources of essential knowledge and highly skilled labor across many countries. The increasing recognition of universities as key drivers for socio-economic development has re-shaped and transformed their traditional missions of teaching and research to adopt the goal of economic development as a third mission over the last two decades (Etzkowitz and Leydesdorff, 2000; Gunasekara, 2006; Arbo and Benneworth, 2007). Universities are expected to play fundamental role in accelerating the scientific and relevant technological innovations and thereby enhancing the economic vitality and competitiveness of a nation through their basic missions of generating and disseminating knowledge - from teaching and research (Geiger, 2006). In this regard, a collaborative link between universities and the industry is necessary for technology transfer and the 
commercialization of academic research. Notably, any technological innovation process implies close linkages among different players - the university, industry and government, and the nature and intensity of the interactions among these actors critically influence the innovative performance of institutions/enterprises within a given innovation system (Nelson; Lundvall and Johonson cited in Schiller and Diez, 2007).

The role of the University as a strategic resource is prominent feature that brings it to the inner circles of any national development agenda. Thus, countries at different or at extremely dissimilar stages of socio-economic and political environments as well as industrial and technological development have tried to use their universities for sustainable development. Ethiopia is not an exception in this regard.

In Ethiopia, the need to accelerate economic growth through human resource development, research and innovation is evident over the past decade. In the successive phases of the country's economic development plans and strategies, the role of universities in human resource capacity building and technological innovations has been identified as one of the key pillars in the economic and social transformation process of the country (see GTP I and II). Recently, the country's vision of being a middle-income country by 2020-2025 is the key driving force for investing on human capital and research-intensive activities. In this regard, universities play critical role in accelerating human development and technological capacity building and ensuring its sustainability. However, there increasing concern about what the universities are actually doing in terms of enhancing economic development through research and formation of human capital. Thus, necessitates for the present paper, which intends to examine what is actually happening in the Universities regarding the links between academic research and economic development. A thorough understanding of the links between university research and economic development in Ethiopia requires a detailed analysis of empirical data from different sources and using different techniques and the underlying assumptions of the entire systems related to economic growth, higher education and national innovation systems but that is beyond the scope of this paper. This paper addresses the following major questions.

1. How does Academic research influence economic development (conceptual issues)?

2. How do universities and industries interact in terms of research and innovation in the Ethiopian context?

3. Given the existing reality, what are the enablers or barriers for a positive link between university research and industry?

4. What can be done to strengthen the link/interaction between universities and industry?

\section{CONCEPTUAL CONSIDERATIONS- ACADEMIC RESEARCH AND ECONOMIC DEVELOPMENT}

Universities have been identified for their potential as key catalyst in the economic development and social transformation of a nation. Development in general and economic development in particular is a multidimensional and multifaceted concept that involves both growth and change.

Several economic and development theories, models and empirical studies confirm a strong relationship between Universities and socio-economic development (Katharina, 2000; Barro and Sala, 1995; Colgan and Young, 2005; Lundvall, 2007, etc). Geiger and Sa Creso (2005), for example, argue that knowledge creation and technological advancement are central to economic competitiveness. Scientific and technological innovation requires new knowledge (through research), human capital (through education), infrastructure (both physical and cyber), and new policies (intellectual property, anti-trust, tax), all of which depends both on public and private investment and upon the capacity of knowledge institutions such as research universities, corporate R\&D, and national laboratories (Duderstadt, 2005).

The process of knowledge generation and subsequent use of it for development is at the core of new growth models. Endogenous growth theories stress the importance of innovation \& technological change as a source of economic growth- a shift from material- and labor-intensive products and processes to knowledge-intensive products and services. In this perspective, innovation refers to the creation, diffusion and use of new ideas and technological advances in an economy, and can take the form of new products, new production processes, new markets and organizations (Yang, 2006). Research \& development is a necessary condition for innovation-bears most directly on technological changes $\&$ thereby drive productivity.

The relationships between higher education institutions and the state, the institutions' traditional knowledge configuration and self-regulation practices as well as their external links have changed over the past years (Gibbons, 1994; Nowotny, Scott and Gibbons, 2003). Universities are expected to respond to the demands of the different stakeholders in their environment through working in partnership with the government and industry/business sectors. Such changing nature of role of Universities has resulted in the emergence of a 'triple helix' model that depicts the linkage between Universities, government and industry. As Etzkowitz, (2003) noted academic-industrygovernment relations are emerging from different institutional starting points in various parts of the world, but for the common purpose of stimulating knowledge-based economic development. These days, institutional 
arrangements that facilitate university-industry- government partnership are in place, and creating links with industry and government has already become one of the missions and mandates of Universities across many countries (the triple helix). There is, however, a major debate that a positive link between academic research \& economic development is not always straight forward - it is a function of many complex and interrelated factors

In the triple helix model, the university is viewed as an archetype of innovation and research-central actor in new knowledge production, the industry epitomizes the users of the outcomes of university research while the government plays the central legal and policy role in speeding up and strengthening the linkage (Nwagwu, 2008). For such partnership to be successful, each actor should understand the other actor's needs and expectations. Hagen (2002) also argues that successful partnerships require a more sophisticated understanding of the complexities involved, the resources required and the adoption of a long term strategic approach if universities are to achieve the objectives of their new transformational role in economic regeneration. This then, is a call for change not only of universities surface structures but also deeper structures of values, beliefs and culture intrinsic to the traditional university role as well as commitment of the participating company to change (ibid).

\section{The Rationale for University-Industry Linkage}

The links between university and industry encourages the use of academic research by industries (Cohen, et al, 2002). It also enables both universities and industries to maximize capitalization of knowledge and technological innovations through knowledge spillover. The main reasons for enhancing university-industry linkage include the following (James, 2004):

- Universities provide a ready pool of graduate and undergraduate students that industry may access for their work requirements

- Technical opportunities exist in industry for faculty and students that may not exist in universities

- Materials/facilities exist in industry for research and educational purpose that may not exist in universities

- Collaborations with industry provide research funding to Universities

- Such collaborations can advance the service mission of Universities

- Collaborations provide for local and regional economic development.

- Universities often have research infrastructure that industry wants.

- Industry outsourcing to universities, to reduce the costs of doing business and increase profits.

\section{Mechanisms to Facilitate Technology Transfer}

The effect of University-Industry partnership on innovation \& productivity of the economy may work through various channels. According to David, et al (2006), two principal mechanisms among others, facilitate the spillover of knowledge from universities to industries.

The first one involves academic/scientific research published in scholarly journals. Academic research is a key ingredient in the institutional identity of universities and an indispensable prerequisite for a successful program of teaching and public service (Weiler and Guri-Rosenblit, Sawyerr, 2008). Academic research is used here to refer to a scientific or scholarly inquiry undertaken by the academia of a given university on scholarly purpose. High quality faculty committed to research and teaching; high quality graduates who want to function with advanced expertise; an intellectual climate that encourages scholarship-an atmosphere of intellectual freedom in which teaching and research can be performed effectively; adequate and dependable research funding; research infrastructure, and high quality leadership are the essential characteristics of high quality research in universities (Bienenstock in Vessuri and Teichler, 2008).

The second type of spillover mechanism involves human capital embodied in students graduating from universities. The research capacity of universities and research and development centers of both public and private sectors to a great extent depends on the quality of human resource in the areas of science and technology (Vught, 2004). Thus, the extent to which universities are able to produce graduates with marketable skills and organize their research capacities for technological innovation and transfer has positive implication to the economic growth of a nation. The effect of University-Industry partnership on innovation and technological changes may also work through various channels viz., University and government research; research \& development performed by industry/business; and foreign knowledge (knowledge generated in other countries) - through buying patents, licenses or know-how from foreign firms, observing competition (e.g. reverse engineering), hiring foreign scientists and engineers- internationalization, interacting with foreign competitors (foreign direct investment), reviewing the scientific and technological literature.

The university-industry interactions/partnerships also involve varieties of activities namely, staff exchange between Universities / research institution and industry; provision of training to industry professionals; endowments by industrial partners; research partnerships and services including collaborative, joint and contract research projects; shared research infrastructure (labs \& equipment, business incubator and technology parks); academic entrepreneurship ( start-ups, spin-off companies), and commercialization of IP (licensing patents). 


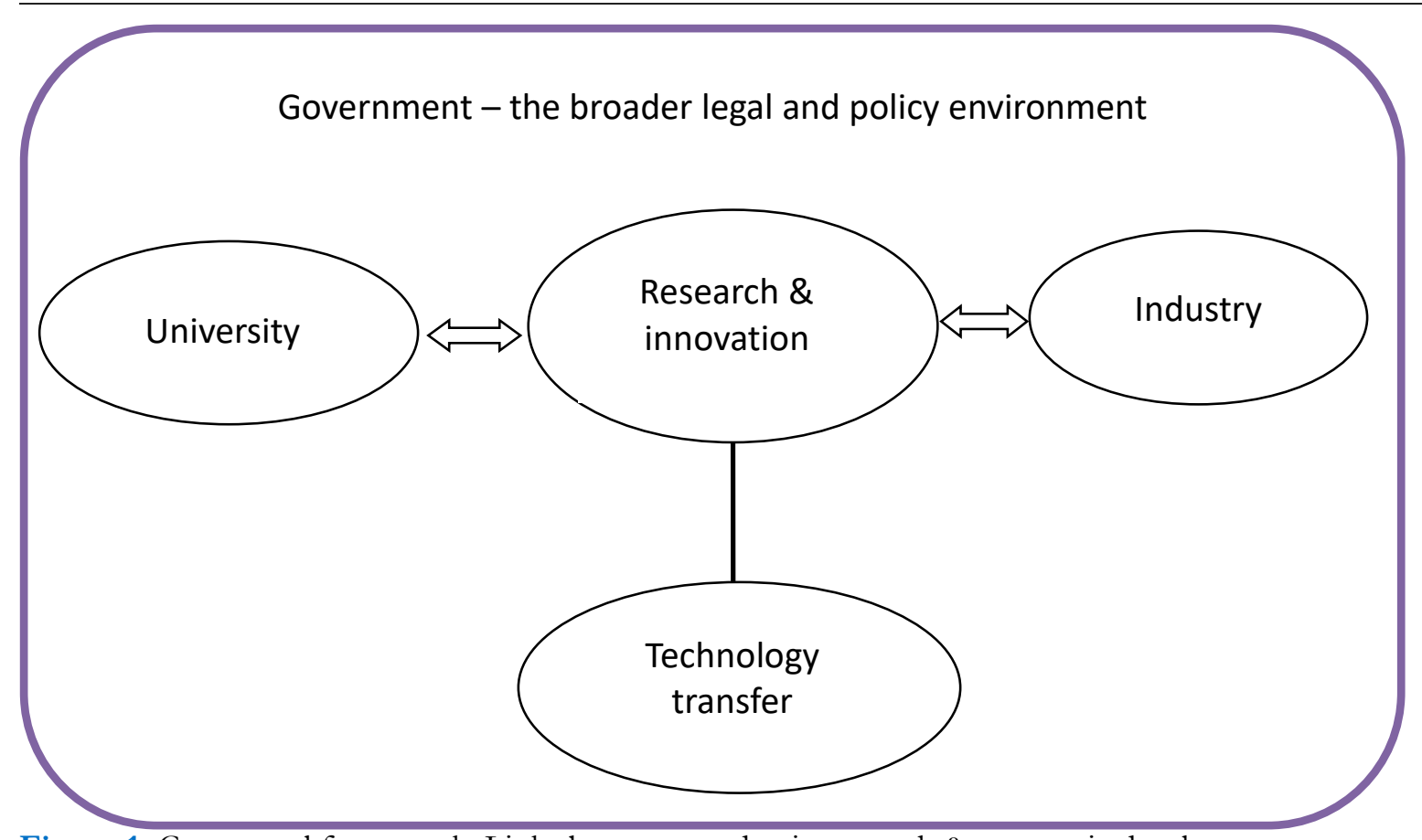

Figure 1. Conceptual framework: Links between academic research \& economic development

\section{Factors That Influence the University-Industry Linkage}

The link between university research and economic development is subject to the influence of many factors. The major contributing factors include among others, University characteristics, industry characteristics and the legal and policy environment, which are briefly described as follows.

University characteristics: this refers to the factors that are internal to the university. These include the motivation and willingness of the University to engage in collaboration with industry in terms of research and innovation; availability of capable and engaged academic core, competent and committed leadership and adequate funding and research infrastructure to produce relevant and quality products (research outputs and graduates). Other factors include availability of policies and supportive internal governance system and procedures for research, innovation and technology transfer; networking and capacity for knowledge transfer to other actors; entrepreneurial mind set; and a research culture.

Industry characteristics: this refers to the factors that are external to the university. In this paper, industry is conceptualized in terms of all the manufacturing and non-manufacturing stakeholders influenced by the products of the University. The extent to which the industrial sector is developed matters a lot for a meaningful and strong partnership with the Universities. The major industry related factors influencing the linkage include readiness and motivation of the industrial sector to engage in partnership with university in terms of research, innovation and technology transfer; availability of adequate research and development infrastructure and personnel; investment(funding) in research and development activities; the absorptive capacity of the industry.

The legal and policy environment. this refers to the legislative and regulative aspects through which governments steer the behavior and operation of organizations in general and universities and the industry in particular. It includes policies, systems and regulatory bodies such as higher education policy and proclamation; Science, Technology and Innovation (STI) policy; national research priorities and strategies; rules and regulations; incentives including national government research funding, matching funds, seed money and tax exemptions; availability of technology parks and regulatory bodies for quality and relevance of education and research. Additionally, the broader political and socio-economic environment also influences the nature of the link/partnership among the three actors viz., the University, Industry and Government. For example, an affective research and innovation system requires support from both political leadership and public opinion; structural conditions; research ethics and values; capability of conducting research and dependable funding.

\section{METHODS}

In this study the link between academic researches and economic development is conceptualized in terms of indicators the number of contract and joint research projects by the universities and industries; Memorandum of 
understanding signed between universities on innovation \& technology transfer, number of patents and commercialized research outputs.

This study employs mainly a descriptive survey method and some key informant interviews. The necessary data regarding the role of university research in economic development are collected through reviews of the existing legal and policy documents (mainly research, technology and innovation policies and strategies), proclamations, guidelines and working papers, national development plans, published reports and meeting notes. Additionally, an attempt has been made to capture theoretical and conceptual issues regarding university-industry linkage from internationally published and unpublished documents. Interviews have also been conducted with some key informants ((MoE, MoST, senior university leadership \& academic staff, \& industry). The key interviewees include 16 from Addis Ababa University (1 senior leadership, 5 middle level leadership, 10 academic staff), 1 each from the Ministry of Education \& the Ministry of Science \& Technology), and 3 from the industry. Due attention is given to identify key enablers or barriers for the positive link. The collected data are properly analyzed and interpreted. The Addis Ababa University is considered as one example to discuss some of the existing experiences regarding university- industry partnership in Ethiopia. The Addis Ababa University is selected based on its age and experience in teaching, research and community service as well as the comparative advantage of its location in the capital in terms of accessing the major business and manufacturing industries concerning teaching and research.

\section{RESULTS AND DISCUSSIONS}

This section presents the results of data analyses. The major findings are organized thematically as follows.

\section{The Institutional Environment}

Results of analyses of documentary evidences indicate that the vision of the country is the key driving force for investing on human capital and research-intensive activities for enhancing knowledge production capabilities of the country. As shown in the national development plans (GTP I and GTP II), a more knowledge-intensive approach to development is increasingly becoming the main route for bringing sustained and outward-oriented development and thereby bringing the country into a middle-income country by 2020-2025. Currently, there is a clear shift from the agricultural led to the industrial led-economy that demands for more quality graduates in the areas of science and engineering, and research \& innovation activities. The universities' role in this regard is accelerating human development and technological capacity building and ensuring its sustainability. This suggests that the institutional environment for universities is changing in the Ethiopian context that demands universities to be responsive to the economic development o the country.

\section{The Legal and Policy Frameworks}

The Ethiopian government has introduced and implemented successive legal frameworks, plans and strategies within the framework of the 1994 education and training policy with the purpose to steer the behavior of higher education institutes. The main national legal and policy frameworks that directly or indirectly influence the link between universities and industry in terms of research and innovation are briefly discussed in the paragraphs that follow.

The 2009 Higher Education Proclamation (650/2009) - is the legal framework for the operation of the higher education system in Ethiopia. This law urges universities to define their core research areas and themes on the basis of the priority needs of the country, the institutions comparative advantages, and in consultation with the key stakeholders (Article 24, No. 2). The proclamation allows universities to conduct joint research projects with other national and international institutions, research centres, and industries (Article 24, No.3). In the proclamation, there is a clear focus on partnerships with industry in terms of research and technology transfer.

The National Science, Technology and Innovation (STI) Policy (MoST, 2016) - this policy, formulated in 2012, envisages the creation of a national framework that will define and support how the country will in future search for, select, adapt, and utilize appropriate and effective foreign technologies as well as addressing the establishment of national innovation system (FDRE, 2012). Research, technology transfer, human resource development, university-industry linkage and intellectual property systems are among the eleven critical policy issues considered in the STI policy directions and strategies. The policy establishes a national STI council and a forum for university-industry collaboration to regulate the national research and innovation priorities and systems.

The Research and Technology Transfer Conceptual and Governance Framework of Ethiopian Higher Learning Institutions (MoE, 2016) - is another new policy framework that defines vision, mission and objectives of research and technology transfer framework including opportunities and challenges. A framework regarding technology transfer, university-industry linkage and directions to strengthen research and technology transfer in the Ethiopian Universities are among the focus areas of this national framework. 
Professional and Program Mix Policy (MoE, 2008) - The policy clearly articulates the 70:30 undergraduate professional mix in favor of science and technology over generally speaking humanities and social sciences. This policy has implications for stimulating university-industry partnership in terms of training and research.

Intellectual property (IP) rights system (MoE, 2008) - Intellectual property rights systems are considered as one of the essential mechanisms to enhance university-industry cooperation and commercialization of research and innovation. A review of the documentary evidences show that the issue of intellectual property rights policy is a recent phenomenon in the Ethiopian context, which traced back to establishment of the Ethiopian intellectual office in 2003. Since then attempts have been made to utilize the IP law as an instrument for technological innovation. However, results of the interview data show that the IP policy is not yet boiled down to the Universities. The major challenges gaps include absence of institutional IP policies in public higher education institutions, research and development organizations as well as public enterprises, and lack of awareness of the value and importance of IP protection is also mentioned as the problem among business enterprises.

The findings in the preceding paragraphs show that the national legal and policy frameworks recognize the role of science and technology for development, promote research \& innovation that enhance knowledge \& technology transfer, and require universities to engage in research including joint research projects with industry that serves the developmental needs of the country. However, the issues on how can university-industry partnerships be stimulated and enhanced in research and technology transfer activities are not well articulated. There is a weak synergy among the legal and policy frameworks in steering the behaviour of the industry and the universities towards meaningful collaboration in research, innovation and technology transfer.

\section{Funding}

Analysis of documentary evidences show that the government expenditure on education has been increasing over the past years, which is about $7 \%$ of GDP in recent years. Currently, education expenditure accounts for about $24.9 \%$ of the total public expenditure and the share of higher education budget from the total education budget has been reasonably high compared to the lower tiers of the education system (MoE, 2016). Public universities account for about $49.5 \%$ of the total education expenditure. However, funding for research and innovation from the government treasury is often insignificant or totally unavailable until 2012 because of soaring student enrolment that favoured allocations to teaching instead of research, and to undergraduate instead of postgraduate training (Fisseha, 2015). In 2011/12, the research budget of all universities accounted for only $1 \%$ of their total budget (MoE, 2015). Recently, $0.62 \%$ of the annual GDP is allocated for research, which is low compared to 3\% in EU, 2.59\% in US and other African countries such as South Africa.

The inadequacy of research funds has been hindering the research and innovation capacity of universities in terms of research infrastructure, facilities and equipment as reported by majority of the respondents. Analysis of documentary evidences and data from key informant interviews with university leaders and academic staff indicate that there are no intermediary funding agencies at national level that focus in stimulating university research and linkages with industries, business sectors and the community. The contribution of industry/business sector in funding university research is almost non-existent in the Ethiopian context.

\section{Governance Structures for Science and Innovation}

At national level, the Ministry of Science and Technology (MoST) has been established by proclamation No. $691 / 2010$ as one of the most important regulatory bodies in the areas of science, technology and innovations. Preparing national science and technology research and development programmes based on the country's development priorities; coordinating science and technology development activities and national research programmes; and facilitating interaction and collaboration among government and private higher education and research institutions and industries with a view to ensure research and technological development are among the seven duties and responsibilities of the Ministry. Similarly, the government has also established national STI council and the national forum for university-industry linkage which are coordinated by MoST.

As one of its strategies to steer the behaviour of different actors, MoST has issued a Procedural Directive for the Linkage of Education and Training, Research Institutions and Industries in 2013. According to this directive, Universities are required to interact with industries in terms of ensuring the development of students' skills through practical trainings and to undertake need-based research that solves problems related to competitiveness of industry. To this end, many of the universities have opened university-industry linkage and technology transfer offices under the vice president for research and technology transfer to facilitate their interaction with industries in terms of training, research and innovation.

The Research and Technology Transfer Conceptual and Governance Framework of Ethiopian Higher Learning Institutions is another new policy framework developed by the Ministry of Education. It defines the vision, mission and objectives of research and technology transfer framework including opportunities and challenges in the universities. Under this framework, institutions will be supported through provision of funding for innovation, 
perhaps on a competitive basis. This shows the intention of the Ethiopian government to facilitate the science and innovation endeavors of the country.

However, results of the interview data from university leaders and staff shows that the national STI council and the national forum for university-industry linkage are not well functioning and their impact in enhancing the link between the industry and universities is minimal. Similarly, the university-industry linkage and technology transfer offices of the universities are not well developed to the level of attracting the industries through relevant and quality research and innovation activities.

\section{Status of University and Industry Interactions in Terms of Research and Innovation}

Results of analysis of documentary evidences and interview data indicate that the university-industry link was generally found to be at its beginning phase due to different reasons. Linking institutional research priorities with the priority need areas in the industry sector was marked by almost all interviewees as a new phenomenon in Ethiopia. The low level of industrialization in Ethiopia currently; shortage of capable researchers at universities ( $\mathrm{PhD}$ holders accounts only for $11.3 \%$ of the total academic staff), and the poor attitude universities had traditionally towards the university-industry link and to its significance are the main challenges for building strong partnerships with industries.

The fact that universities are just starting working in consultation with industries and thus their experience of so doing is quite immature was explained by two factors. The first one was the fact that Ethiopia is just launching the scheme of industrialization very recently and they have never been many industries as such to work with. And the second one is the low level of awareness and experience by higher education institutions that industries play an extremely important place in the training of graduates and later in their deployment for work. One of the respondents from Addis Ababa University stressed that the development of linkage between the universities and industry in Ethiopia is an emerging one, a relationship that has yet started but started in a positive way. Given the low level of industrial expansion, inability to sort out needs and limited capacity to project markets on behalf of the industry and low level of awareness of universities to tie up their programs with industry, the link between universities' institutional research agenda and needs of industry and society is at a lower stage currently.

Interviews from the industrial sector on their part reported that the capacity of the universities in producing commercially attractive research and innovation outputs and graduates is one of the major challenges for strengthening their partnership with the universities. As one of the respondents from the industry reported, the industries prefer to import experts from abroad with fewer prices compared to the local universities to address their technical and knowledge constraints. This suggests that the readiness and willingness to engage in collaboration is yet to be developed in both the universities and the industrial sector.

Respondents from the Addis Ababa University, industries and Ministry of education witness that contract and joint research projects, commercialized research outputs, and patents are almost non-existent. As one of the interviews from the Addis Ababa University noted, there are only two international patents from universities in about 7-decade history of higher education in the country. Another respondent from the industry noted that though there are some memorandum of understanding between industries and universities (particularly with the old universities), the impact of the research outputs in terms of innovation and technology transfer are not emerged as intended. This shows that the link between academic research and economic development at national level is not well developed, though the issue is well articulated at policy level.

\section{The Case of Addis Ababa University- The State of University-Industry Link}

Addis Ababa University, as a pioneer higher education institution, has been playing its critical role in the formation of human capital in the country. It has been articulating research undertaking as one of its missions since its establishment in 1950. The movement to establish a link between the university's research and training to industry began to the 1980s that culminated with the formation of a University-Industry Cooperation Program in 1986 (see Daniel, 2008 and Fetene, 2014). The university has also made a similar attempt to establish a link with industry in 2000. However, all this attempts could not be translated into meaning action due to lack of adequate and coordinated efforts to stimulate a sustainable institutional linkage between the university and industry (Ibid.).

Engagement in mutually rewarding on-going collaboration with its stakeholders is still one of the missions of the Addis Ababa University. Recently, the university has put in place policies and thematic priority areas for research and offices to coordinate and lead research, university-industry linkage and technology transfer since 2010. There is also an increasing in fund allocation for research since 2012. Even though the overall scenario for collaboration and working with the industry appears to be limited, relative strengths were reported in the interviews conducted. Many respondents from the university explained that public universities especially the Addis Ababa University engage the public in setting out their institutional research agenda and in opening up new programmes. This is possible they underlined in the needs assessment academic programmes are required to carry out prior to designing new programmes of studies. Stakeholders from the public are invited to get engaged in the needs analysis 
process thereby articulating their needs and interests. The respondents also mentioned the opening of a director's office in Addis Ababa University to solely address the link between university and industry is an important step the university took to address the needs of the sector.

However, the role of academic research in terms of enhancing the productivity of the economic sector is generally dismal. Most of the research works undertaken by the academic and research institutions \& $\mathrm{PhD}$ students are either shelved or presented in conferences or published in journals for the purpose of academic promotion. The research results are contributing in terms of ideas and policies, but do not reach the market in terms patents, commercialized research outputs and technologies for the industry. As one of the interviewees noted, no research results carried out by staff are changed into patents or technologies. For example, Addis Ababa University through its history gets only two patent internationally so far, as reported by the respondent. Hence the contribution of the Addis Ababa University in strengthening partnership with the private sector and enhancing the economic growth of the country through academic research and innovation is minimal.

\section{Enablers for and barrier to a positive link between university research and industry}

From the findings discussed in the preceding sections, the availability of governance structure at national and institutional levels; the existing policies science, technology and innovation and the current shift of the country towards industrialization may be considered as enablers or opportunities to strengthen the university-industry linkage in terms of research and innovation. However, the link between academic research and economic development is constrained by a multitude of factors. The major barriers for a positive link between universities and industries include.

- Lack of robust and overarching national framework that brings all actors (university, industry and government) on board to collaborate in research, innovation and technology transfer. The existing policy frameworks lack coherence and synergy to ensure strong partnership between industries and universities in terms of research and innovation.

- Lack of readiness and willingness on both the universities and industries to engage in meaningful partnership,

- Limited attention and inadequate funds for research \& innovation at national level,

- Absence of well-established research infrastructure \& facilities dedicated for research \& innovation activities in both the industries and universities. The industrial sector is at an infantry stage and investment in research and development is yet to be developed in the sector,

- Inadequate institutional commitment and support at all levels,

- Shortage capacity/capable staff to undertake advanced research- Staff with PhD qualification accounts for only $11.3 \%$ of the total academic staff of the universities.

\section{CONCLUDING REMARKS}

This paper shows that the role of university research in economic development is vital. However, a positive link between university research and economic development is subject to the influence of many factors that are internal and external to the university. The findings indicate that University-industry partnership in terms of research, innovation and technology transfer is very weak in the Ethiopian context. Many of the enabling conditions are lacking. Particularly, the contribution of the Addis Ababa University in strengthening partnership with the private sector and enhancing the economic growth of the country through research and innovation is minimal. The role of the private sector in strengthening their partnership in terms research and development, innovation and technology transfer is yet to be developed. Thus, the university, private sector, and the government should take their share in creating strong linkages \& partnerships necessary to enhance the economic growth of the country. This requires a robust national framework to enforce strong linkage among the three actors.

\section{REFERENCES}

Arbo, P. and Benneworth, P. (2007). Understanding the Regional Contribution of Higher Education Institutions: A Literature Review. OECD Education Working Papers, No. 9, OECD Publishing. https://doi.org/10.1787/161208155312

Asgedom, A. (2007). Academic Freedom and Development of Higher Education in Ethiopia: The Case of Addis Ababa University. UK: University of East Angelia (PhD Dissertation).

Audretsch, D., Keilbach, M.C. and Lehmann, E. (2006). Entrepreneurship and Economic Growth, Oxford University Press. https://doi.org/10.1093/acprof:oso/9780195183511.001.0001

Barro, R. and Sala, X. (1995) Economic Growth, Second edition. The MIT Press, Massachusetts: London. 
Bollinger, A. and Smith, R. (2001). Managing organizational knowledge as a strategic asset. Journal of Knowledge Management, 5(1), pp. 8-18. https://doi.org/10.1108/13673270110384365

Cohen, W.M., Nelson, R.R. and Walsh, J.P. (2002). Links and Impacts: The Influence of Public Research on Industrial R\&D. Management Science, 48(1), pp. 1-23. https:// doi.org/10.1287/mnsc.48.1.1.14273

Cyert, R.M. (1991). Knowledge and Economic Development. Operations Research, 39(1), pp. 5-8. https://doi.org/10.1287/opre.39.1.5

Daniel, K. (2008). Higher education- industry resource integration center: Towards solving existing industrial problems. In H. Etzkowitz, eds. Transforming university-industry government relations in Ethiopia, proceedings of Ethiopian Triple Helix Conference. Sweden: IKED.

Duderstadt, J.J. (2005). University-Indusy-Government Partnership for a 21st century Global, Knowledge driven Economy: An American Perspective. US: University of Mitchigan.

Etzkowitz, H. (2003). Innovation in Innovation: The Triple Helix of University-Industry-Government Relations. The Social Science Information, 42(3), pp. 293-337. https:// doi.org/10.1177/05390184030423002

Etzkowitz, H. and Leydsdorff, L. (2000). The dynamics of innovation: From national systems and "Mode 2" to a Triple Helix of university-industry-government relation. Research Policy, 29(2), pp. 109-123. https://doi.org/10.1016/S0048-7333(99)00055-4

FDRE (2003). Higher Education Proclamation (No 351/2003). Addis Ababa: Negarit Gazeta.

FDRE (2003b). A proclamation to provide for the establishment of the Ethiopian IP Office proclamation (No 320/2003). Addis Ababa: Federal Negarit Gazeta.

FDRE (2009). Higher Education Proclamations (No 650/2009). Addis Ababa: Negarit Gazeta.

FDRE (2014). National Research Ethics Review Guideline. Addis Ababa, Ethiopia.

Geiger, R.L and Sá, C. (2005). Beyond Technology Transfer. Us State Policies to Harness University Research for Economic Development. Minerva, 43(1), pp.1-21. https://doi.org/10.1007/s11024-004-6623-1

Geiger, R.L. (1985). Research Universities: Their Role in Undergraduate Education. In Contexts for Learning: The Major Sectors of American Higher Education. Washington, DC: GPO, pp. 49-65.

Geiger, R.L. (2006). The Quest For 'Economic Relevance' by US Research Universities. Higher Education Policy, 19(4), pp. 411-431. https://doi.org/10.1057/palgrave.hep.8300131

Gibbon, M. Limoges, C., Nowotny, H., ... Trow, M. (1994). The New Production of Knowledge: Science and Research in Contemporary Societies. London: Sage.

Hall, H.B. (2004). University-Industry Research Partnership in the United States. University of California. Conference paper.

Howells, J. and McKinlay. (1999). Commercialization of University Research in Europe. Report to the Advisory Council on Science and Technology, Ontario, Canada.

Katharina, M. (2000). Returns to Education in Low Income Countries: Evidence for Africa. [online] Available at: http://www.hwwa.de/Projects/Res_Programmes/RP/Development_Processes/VfS_EL_2000_Rev

Lundvall, B. (2007). Higher Education, Innovation and Economic Development. Denmark: Aalborg University.

Mamo, F. (2015). Revenue Generation Strategies in Sub-Saharan African Universities. Enschede: University of Twente, Enschede.

Ministry of Education (MoE) (2008). Annual Intake and Enrolment Growth and Professional and Program Mix of Ethiopian Public Higher Education: Strategy and Conversion Plan,2008/09-2011/12. Unpublished. Addis Ababa: Federal Democratic Republic of Ethiopia.

Ministry of Education (MoE) (2009/10). Education Statistics Annual Abstract. Addis Ababa: Federal Democratic Republic of Ethiopia.

Ministry of Science and Technology (2012). Science, technology and Innovation policy. Addiss Ababa, Ethiopia.

Ministy of Education (MoE) (2014/15). Education Statistics Annual Abstract. Addis Ababa: Federal Democratic Republic of Ethiopia.

MoFED (2010). Growth and Transformation Plan (GTP) 2010/11-2014/15. Addis Ababa: Federal Democratic Republic of Ethiopia.

National Plan Commission (2015). The Second Growth and Transformation Plan (GTP II) 2015/61-2019/20. Addis Ababa: Federal Democratic Republic of Ethiopia.

Nega, M. (2012). Quality and Quality Assurance in Ethiopian Higher Education: critical issues and practical implications. Enschede: University of Twente, Enschede.

Nwagwu, W.E. (2008). The Nigerian University and Triple Helix Model of Innovation systems: adjusting the wellhead. Technology Analysis \& strategic Management, 20(6). https://doi.org/10.1080/09537320802426374

Pillay, P. (2008). Higher Education and Economic Development - A Review of the Literature. Draft, unpublished. Cape Town: Centre for Higher Education Transformation. 
Regassa, F. (2014). University-Industry Linkages in Institutions of Tecbnology \& Natural Science Fields in Ethiopia: The cases of Addis Ababa, Adama Science \& Technology and Babirdar Universities. Ethiopia: Addis Ababa University (unpublished $\mathrm{PhD}$ dissertation).

Saint, W. (2004). Higher Education in Ethiopia: The Vision and Its Challenges. JHEA/RESA, 2(3), pp.83-113.

Schiller, D. and Diez, J.R. (2007). University-industry Linkages. Potential and realization in developing countries: Thai experience. TECH Monitor, Jan-Feb-2007, pp. 38-44.

Schultz, T.P. (1994). The Formation of Human Capital and the Economic Development of Africa: Returns to Health and Schooling Investments. African Development Bank, Economic Research Papers, No. 37.

Scot, S. (2004). Variation in Spinoff Activities Across Institutions. In Academic Entrepreneurship: University Spinoffs and Wealth Creation. Edward Elgar Publishing.

Tiwana, A. (2002). The Knowledge Management Toolkit, Prentice Hall PTR, NJ, USA.

UNESCO (2000). A decade of Investment in Research and Development (R\&D): 1999-2000. UIC Bulletin, No 1.

UNESCO (2004). Higher Education in a Globalized Society. UNESCO, Paris.

UNESCO (2004). World Bank Document: Improvement of Capacity of Higher Education Institutions through Doctoral Training. UNESCO, Paris

UNESCO (2010). UNESCO Institute for Statistics. UNESCO, Paris.

Van Vught, F. (2004). Closing the European Knowledge Gap?. Challenges for the European Universities of the 21st Century. http://www.humane.eu/fileadmin/wsan_docs/ws2004/ws2004_Mon_Van_Vught_3_Closing_Knowledge_ Gap.pdf

Van Vught, F. (2006). A supranational European University Policy. An Analysis of the European Union Higher Education and Research Policies. Pobrane, 25.

Vessuri, H. and Teichler, U. (2008). Universities as Centers of research and Knowledge Creation: An Endangered Species. Rotterdam: Sense Publishers.

Weiler, H.N, Guri-Rosenblit, S. and Sawyerr, A. (2008). Universities as Centers of Research and Knowledge creation. In H. Vessuri and U. Teichler, eds. Universities as Centers of research and Knowledge Creation: An Endangered Species. Rotterdam: Sense Publishers.

World Bank (2000). Higher Education in Developing Countries: Peril and promise. Washington, DC: WorldBank.

World Bank (2010). Financing Higher Education in Africa. Washington, DC: WorldBank. https://doi.org/10.1596/978-0-8213-8334-6 